\title{
Correlation Learning Style with Grade Point Average Fourth Year Medical Student
}

\author{
Resti Rahmadika Akbar*(D), Elvinas Sari Nasution (D) \\ Department of Medical Education, Faculty of Medicine, Universitas Baiturrahmah, Padang, Indonesia
}

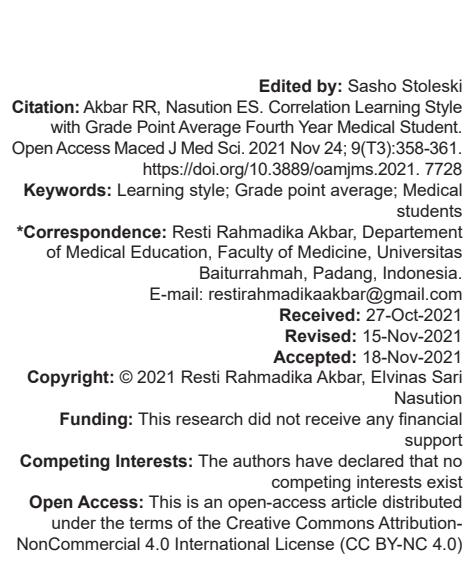

\section{Introduction}

Learning achievement is an important indicator to measure the success of the learning process and the instructor. Learning objectives are for behavioral change that is expected to be achieved by someone after carrying out a learning process [1], [2]. Factors that can affect the learning outcomes of each student are internal factors, factors that originate from the individual, while external factors are factors that come from outside the individual. Many things include internal and external factors, including learning styles and achievement index. Learning styles are very influential in the process of learners and instructors, because if everyone has understood their learning styles each will be quick and easy in accepting new information or knowledge [3], [4].

According to Al-Saud's study, the percentage of learning in $1^{\text {st }}$-year Dentistry students at one institution in Saudi Arabia found that $59 \%$ of students had a single learning style. Significant differences were found in the percentage of learning styles with a Grade Point Average (GPA), by comparing the GPA of a student's GPA with the highest. Respondents who had a "D" GPA had a low cumulative achievement index, causing comparisons with other values that did not reach statistical significance.
Students with a "C" GPA show an increased preference for unimodal learning styles when compared to a GPA " $A$ " which is more likely to have bimodal and quad model preferences. From the study dentistry students, who found learning and were associated with a higher or lower GPA in the students surveyed [3], [5].

Based on an initial survey conducted on 10 students, the results of the learning styles trimodal 3 people $(30 \%)$, and quad model 7 people $(70 \%)$. Whereas the learning achievement category passed 4 people (40\%), satisfying 3 people $(30 \%)$, and very satisfying 3 people $(30 \%)$ [3]. From these results, the relationship between learning styles and learning achievements is obtained. Based on the description above, the author is interested in researching the relationship of learning styles to the cumulative achievement index (GPA) of $4^{\text {th }}$-year students of the Faculty of Medicine at Baiturrahmah University.

\section{Method}

This research is a correlative analytic study with a cross-sectional design. The target population 
in this study were students of the Faculty of Medicine at Baiturrahmah University. The affordable Data was collected through an online visual-aural-read/writekinesthetic (VARK) questionnaire using Google Form, respondents were collected and socialized about how to fill out an online questionnaire. Data obtained from the studied variables will be collected, processed, and analyzed using SPSS (Statistical Product And Service Solution). Data management as a form of bivariate analysis to see the relationship of learning styles to the cumulative performance index (GPA) using the Spearman test. Univariate analysis is carried out to determine the magnitude of proportions according to characteristics, learning styles, and cumulative achievement index (GPA). Bivariate analysis is used to explain the relationship between the independent variable (learning style) and the dependent variable (GPA) using the Spearman statistical method because this study looks for the relationship of learning style (categorical) with cumulative achievement index (categorical).

\section{Results}

\section{Characteristics of respondents}

Based on the research conducted, obtained a descriptive description of gender and place of residence in students at the Faculty of Medicine, Universitas Baiturrahmah as in the following Table 1:

Table 1: Characteristics of respondents

\begin{tabular}{lll}
\hline Characteristics of respondents & $\mathrm{f}$ & $\%$ \\
\hline Sex & & \\
$\quad$ Male & 23 & 28.8 \\
$\quad$ Female & 57 & 71.3 \\
Place of residence & 74 & 92.5 \\
$\quad$ Rent & 6 & 7.5 \\
$\quad$ Living with parents & 80 & 100 \\
$\quad$ Total & \\
\hline
\end{tabular}

Based on Table 1, the results obtained from 80 students were mostly female, consists of 57 female $(71.3 \%)$, and the most residential rent was 74 people $(92.5 \%)$ in the $4^{\text {th }}$-year students of the Faculty of Medicine, Universitas Baiturrahmah.

\section{Learning style}

Based on research conducted, obtained distribution of learning styles as in the following Table 2:

Table 2: Distribution of learning styles

\begin{tabular}{lll}
\hline Learning style & $\mathrm{f}$ & $\%$ \\
\hline Uni-model & 3 & 3.8 \\
Bi-model & 2 & 2.5 \\
Tri-model & 11 & 13.8 \\
Quad-model & 64 & 80.0 \\
Total & 80 & 100 \\
\hline
\end{tabular}

Based on Table 2 the results obtained from 80 respondents, most of them have a quad-model learning style of 64 students in $4^{\text {th }}$ year $(80 \%)$ of the Faculty of Medicine, Universitas Baiturrahmah.

\section{GPA}

Based on research conducted, obtained the distribution of GPA as in the following Table 3:

Table 3: Distribution of GPA

\begin{tabular}{lll}
\hline GPA & $\mathrm{f}$ & $\%$ \\
\hline Graduated & 49 & 61.3 \\
Satisfying & 22 & 27.5 \\
Very satisfy & 9 & 11.3 \\
Total & 80 & 100 \\
\hline
\end{tabular}

Based on Table 3 the results obtained from 80 respondents, most have a grade achievement index (GPA) which is graduated $(61.3 \%)$ in the $4^{\text {th }}$ year students of the Faculty of Medicine, Universitas Baiturrahmah.

\section{Correlation of learning style with gpa $4^{\text {th }}$ year student medical faculty}

Following are the results of research on the relationship of learning styles with the 4th-year GPA of the Faculty of Medicine at Universitas Baiturrahmah in the Table 4 below:

Table 4: Correlation of learning style with GPA $4^{\text {th }}$ year student medical faculty

\begin{tabular}{lll}
\hline GPA & & \\
\hline Learning style & $\mathrm{p}$ & $\mathrm{r}$ \\
\cline { 2 - 3 } & 0.024 & 0.253 \\
\hline
\end{tabular}

Based on Table 4 the statistical test results (spearman) obtained the value of $p=0.024(p<0.05)$ and $r=0.253$, it can be concluded that there is a relationship between learning styles and GPA of $4^{\text {th }}$-year students of the Faculty of Medicine, Universitas Baiturrahmah. The closeness of the relationship between the two variables shows the coefficient $(r)=0.253$ means the level of correlation of the variables in the weak category with a positive direction, meaning that the more varied the learning style, the higher the GPA of respondents will increase.

\section{Discussion}

\section{Characteristics of respondents}

Based on the research, obtained the results of sex was female that is 57 people $(71.3 \%)$ of $804^{\text {th }}$-year students Faculty of Medicine. The results of research conducted by experts on gender differences, the size of the brain can not affect a person's intelligence, but the habits or behaviors that make it make a difference. In academic abilities that include language, mathematics, and natural sciences, $70 \%$ of countries in the world show that women have better grades. This shows that culture and environment influence achievement, environmental influence can bring oneself to success. One of them is the external factor in the learning environment in the form of a place to live (boarding house, house, or rent house) [6]. 
The results based on residential were rent about 74 students $(92.5 \%)$ in the $4^{\text {th }}$ year students. Research in Tadulako obtained the most students who did not live with his parents were 94 people (55.29\%), followed by students who lived in his parents' home as many as 69 people (40.59\%) [6]. However, based on the results of this study, students from outside the city of Padang may have adapted to the culture of Padang well. This is because the average student has lived in Padang for quite a long time since the first semester of college so that the adaptation process has occurred.

\section{Learning style}

Based on the research obtained from 80 respondents, most of them have a quad-model learning style of 64 students (80\%). Students who choose a unimodal learning style only learn by focusing on one type of learning method. Those who choose visual focus on learners who use media images, diagrams, graphs and who choose auditory will focus on hearing, so attending class lectures and discussions is very important for this learning style model. Likewise, with other learning styles, all have their learning focus.

The most student learning style models in this study are quad-model. VARK learning style is a division of learning style models based on sensory perception, namely the sense of acceptance. Students who have an auditory model of learning style will love learning with lectures, lectures, discussions, listening and answering questions. Students with a model of learning to read/ write prefer to read, write, make diagrams, graphs, and others [3].

Learning styles can form because of habits and can change over some time. Nuzhat found that the learning styles of medical students in Saudi Arabia using the VARK questionnaire, the results of the study found that the most learning styles of students were quad-model $72.6 \%$, while for the most unimodal was auditory $11.6 \%$ [5].

In the opinion of De Poter and Hernacki that auditory learning styles are more dominant in using the sense of hearing to conduct learning activities. Therefore, $4^{\text {th }}$-year students of the Faculty of Medicine Universitas Baiturrahmah who have an auditory learning style will have difficulty when reading material when their friends are busy in class, they can not concentrate if there is a commotion, cannot even focus on learning if there is music playing with volume the big one. This is because students with auditory learning styles are more likely to use their ears as learning media so that if other sounds are coming from outside they will not be able to concentrate on learning [7], [8].

While the kinesthetic learning style possessed by $4^{\text {th }}$-year students is in line with verbal activities. This is consistent with the opinion of De Poter and Hernacki which states that people with this learning style are easier to grasp lessons when they move, feel, or take action. This is what makes the $4^{\text {th }}$-year students with kinesthetic learning style tend to not be able to memorize the material by memorizing, preferring physical contact with others, even speaking very slowly when making presentations in class [3], [9], [10]. Following the student-centered learning that is applied at the Faculty of Medicine, Universitas Baiturrahmah and requires facilities that can support the learning process of students with these learning styles.

Obligations of instructors in managing teaching methods to create a learning environment that is suitable for all models of student learning styles Activities that can be carried out to suit all models of learning styles are varying ways or methods of teaching such as group learning (Tutorial) interactive lectures, projects, to the field (for medical students can go to hospitals, health centers, communities, etc.), and team-based learning [11].

\section{Grade performance index (GPA)}

Based on this study the results obtained from 80 respondents, most of them have a GPA) which is graduated (61.3\%). In addition, the student's approach to the task determines the extent to which students are involved with the subject and influences learning outcomes. A deep approach to learning is characterized by a desire to understand and search for meaning, which encourages students to try to connect concepts with existing understanding and with one another, distinguish between new ideas and existing knowledge, and critically evaluate and determine themes and concepts. A surface approach to learning is characterized by a desire to complete tasks, memorize information, not discriminate between new ideas and existing knowledge, and treat assignments as forced from the outside [6], [7], [11].

\section{Correlation of learning style with GPA $4^{\text {th }}$ year student medical faculty}

Based on the research, the results of the statistical test (correlation) obtained the value of $r=0.253$ with a value of $p=0.024(p<0.05)$, it can be concluded that there is a relationship of learning styles with the GPA of the $4^{\text {th }}$-year students. The closeness of the relationship between the two variables shows the correlation coefficient $(r)=0.024$ is the level of variables in the weak category with a positive direction, meaning that the more varied the learning style, the GPA will increase the respondents.

In line with the research conducted by Demak, results obtained there is a relationship between learning styles and anatomical testament in Tadulako University medical students and Rahmayani research, the results of the influence of learning styles on student achievement in medical education at Hasanuddin University [7], [8]. 
In the learning process, no way of learning is considered right or wrong because everyone has different learning styles that give the advantages and disadvantages of each. When students can understand their learning styles, the student learning process will be more effective and efficient. To find out the training sorts of each individual, further discussion is required regarding more detailed learning styles and what steps students can fancy choose learning strategies that are in line with the training styles they need [7], [8], [9], [11].

The results of this study, the contribution is given learning styles to the value of GPA is weak, this is due to students not yet aware of the learning styles they have so that in doing the learning process not yet getting maximum results. The difference in influence between each learning style on a student's GPA is reasonable, but it must be realized by the individual concerned so that it can be used as an advantage to be developed in achieving a satisfactory GPA. Therefore every individual needs to know the tendency of his learning style.

\section{References}

1. Hamalik O. Proses Belajar Mengajar. Padang: PT Bumi Aksara; 2013.

2. Yamin M. Desain Pembelajaran Berbasis Tingkat Satuan Pendidikan. Jakarta: Gaung Persada Press; 2007.

3. Sarabi-Asiabar A, Jafari M, Sadeghifar J, Tofighi S, Zaboli R, Peyman $\mathrm{H}$, et al. The relationship between learning style preferences and gender, educational major and status in first year medical students: A survey study from Iran. Iran Red
Crescent Med J. 2015;17(1):e18250. https://doi.org/10.5812/ ircmj. 18250

PMid:25763269

4. Pendidikan P, Kedokteran S, Kedokteran F, Diponegoro U. Pengaruh Gaya Belajar Terhadap Prestasi Akademik Mahasiswa Fakultas Kedokteran Jurnal Media Medika Muda; 2014.

5. Gilakjani AP. Visual, auditory, kinaesthetic learning styles and their impacts on English language teaching. J Stud Educ. 2011;2(1):104. https://doi.org/10.5296/jse.v2i1.1007

6. Hasianna ST, Surawijaya AK, Maulana TA. Semester Satu D Fakultas Kedokteran Universitas Kristen Maranatha Tahun 2014. Description of Anxiety Level in Maranatha Christian University Faculty of Medicine First Semester Students in 2014; 2014.

7. Abdillah R, Pamungkasari EP, Damayanti KE. The Influence of Learning Style on Student Achievement in the First Year of the Faculty of Medicine, Sebelas Maret University, Surakarta. Nexus Pendidik Kedokt Kesehat. 2017;6(1):59-66.

8. Demak IPK, Irsan M, Hutasoit GA, Asriadi. The relationship between learning styles and the value of anatomical tentaments for medical students at Tadulako University. J. Kes Tadulako. 2018;4(2):1-65

9. Rezigalla AA, Ahmed OY. Learning style preferences among medical students in the College of Medicine, University of Bisha, Saudi Arabia (2018). Adv Med Educ Pract. 2019;10:795-801. https://doi.org/10.2147/AMEP.S219176

PMid:31565016

10. Hernández-Torrano D, Ali S, Chan CK. First year medical students' learning style preferences and their correlation with performance in different subjects within the medical course. BMC Med Educ. 2017;17(1):131. https://doi.org/10.1186/ s12909-017-0965-5

PMid:28789690

11. Buşan AM. Learning styles of medical students-implications in education. Curr Health Sci J. 2014;40(2):104-10. https://doi. org/10.12865/chsj.40.02.04

PMid:25729590 